\title{
STONE IN THE PELVIC PORTION OF THE URETER.
}

Dr. George E. Brewer presented a man, fifty-two years old, who was referred to the speaker by Dr. Frank H. Whittemore, of New Haven. After a period of ill-health lasting about six months, the patient had an attack of renal eolic on the right side. From this he recovered, but six weeks later he had another severe attack, which in passing off left a good deal of soreness persisting for several days. Examination showed a point of decided tenderness about one inch above the external abdominal ring. Palpation in the region of the kidney itself was negative. The patient stated that during his two attacks the pain racliated down into the groin, as in stone in the kidney. The eystoscopie examination was negative, other than the fact that the right nreteral orifiee was a little prominent. Examination of the urine was negative. An X-ray exannination showed a stone in the pelvie cavity, about lialf an inch from the spine of the ischium. $A$ diagnosis was made of stone lodged low clown in the ureter, and an operation advised. Under ether anæesthesia an eight-inch abdominal ineision was made above and parallel with Poupart's ligament, dividing the various layers tuntil the subperitoneal space was reached and the iliae vessels exposed. The ureter was followed downward. It was found moderately thiekened below the brim of the pelvis, and, on aecount of the dense adhesions, was recognized with diffieulty. No stone conld be detected. An incision was then made in the ureter and a flexible sound introduced and passed downward. This was arrested at the bladder wall. After a prolonged search with the funger, a stone could be felt low down in the ureter. In order to extract it, a second incision was made in the ureter, very low in the pelvis. After removal of the stone, the two incisions in the ureter were earefully elosed; the external wound united by layer suture, leaving a cigarette drain leading down behind the peritoneum. The operation, which required an hour and forty-five minutes, was not followed by any reaction, and the patient made an uneventful recovery. There had been no recurrence of his symptoms.

In reply to a question, Dr. Brewer said that, as a rule, in these operations the ureter was lifted with the peritoneum, with which it was in intimate relationship; but in this particular case it was held down by adhesions to the underlying structures. In a ease 
of ureteral calculus that he reported about a year ago, tenderness was elieited by reetal palpation, but that symptom was entirely absent in this ease.

In reply to a question as to what conrse he would pursue in a case where the $\mathrm{X}$-ray disclosed a calculus in each ureter, Dr. Brewer said that he had such a case under his observation. The patient was a woman, and he advised her to drink large quantities of Poland water. She did so, and under this treatment the pain on one side had disappeared, althongh it was still very severe on the other. He intended to take another $\mathrm{X}$-ray pieture, and if this showed that one of the stones had disappeared, he would advise operating on the ureter that was still occluded.

Dr. Brown said that in some cases the presence of a fairsized stone or several stones in the ureter interfered very little apparently with the aceess of urine to the bladder, and any appreciable hydroneplirosis was often absent.

The spcaker reported the case of a man, seventy years old, who for two years had complained of symptoms pointing to bladder involvoment. There were some pyuria, frequent urination, and a bladder that was intolerant of more than one ounce of any irrigating fluid. He suffered some pain and inereased irritability if driving, whieh lad been given up on that aeeount. Several surgeons at different times had inferred that these symptoms were due to "cystitis," "vesieal ealculus," "enlarged prostate."

Dr. Brown's examination satisfied him that neither of the last two existed, and, suspecting ureteral calculus, had several skiagraphs made by two different experts; four of the plates were corroborative, and showed five calculi in the lowermost part of the left ureter, and two at a higher level in the right. An unsatisfactory cystoscopy suggested a tumor referable to the left ureter, and was adjudged a prolapsus of this tube, due to the stones. This inference was supported by the fact that the row of five stones was at a decided angle with the normal direction of the ureter, and that all the stones were much nearer the median line than was the normal position of a ureter moutl..

In another ease, where symptoms of ureteral calculus had persisted for fourteen years, there was no hydronephrosis. Here an X-ray-plate showed four calculi in the lower part of the left ureter.

Dr. Brown was asked to catheterize the ureters, and was able 
to pass the finest eatheter beyond at least one, if not more, of the stones, and he injected a sterile solution. Whether because of this examination or a mere coincidenee, the patient nevertheless passed all of the stones from the bladder and handed them to the expectant surgeon when about to operate two days after the ureteral eatheterization.

Dr. Brewer said it must not be assumed that every sladow disclosed by the $\mathrm{X}$-ray in the region of the ureter was a stone. It had been shown by Leonard that certain small shadows in this region resulted from the presence of plilebolites or ealeified lymph glands.

Dr. Lilienthat, said that in a ease where the radiograph gave shadows that looked like stones, and the patient gave symptoms pointing to the presence of ealculi, it was pretty safe to asstume that we had to ceal with caleuli. In addition to the possible sourees of error mentioned by Dr. Brewer, namely, phlebolites and ealeified lymph nodes, therc was one other that he had seen illustrated in a ease of suspected ureteral calculns. The pieture gave a shadow that bore a close resemblance to a ealeulus, but Mr. Caldwell, who took the X-ray, said he was convinced that it was not a stone, but a sesamoid bone, such as sometimes occurred in one of the obturator tendons.

\section{SOME OBSERVATIONS ON PROSTATIC ABSCESS.}

Dr. Samulil Alexander real a paper with the above title.

Dr. Brown said that, in lis experienee, prostatic abseess was eomparatively rare. He could recall, perhaps, four or five eases, and in two of those rupture had already taken place into the ischioreetal fossa.

Dr. LiLientiral said that, in opening a prostatic abseess, he conld see no advantage in opening the uretlura; this, on the eontrary, was rather a disadvantage, unless one had to deal with an old chronic abseess, and a fistulous opening into the urethra, where it would be advisable to curette and drain. In an ordinary acute case of prostatic absecss he favored the old-fashioned way of going in directly throngh the perineun into the capsule of the prostate and draining. This method was rapid and safe, no traurnatism was inflicted on the urethra, and it was not neeessary to pass any sounds. The speaker said he saw no serious 